\title{
Witold M. Orłowski Stabilność finansowa Unii Europejskiej: czy potrzebne są kolejne reformy?
}

\section{Financial stability of the European Union: are further reforms necessary?}

The article deals with reforms aimed at strengthening the financial stability of the eurozone and the EU. First, it refers to the "original sin" of the eurozone and the errors committed during its construction in the early 1990s. Then, the lessons from the double crisis of 2007-2009 and 2010-2012 are analysed, and the four main dilemmas that the EU faces in the area of institutional reforms are formulated. The overview of the implemented reforms and their proven impact on the macroeconomic imbalances leads to the conclusion that - although the above-mentioned double crisis combined with the global pandemic crisis have already mobilised the EU to introduce many important changes - the reform agenda is still not finished.

\begin{tabular}{r|l}
\hline DOI & https://doi.org/10.31268/StudiaBAS.2021.24 \\
\hline Słowa kluczowe & $\begin{array}{l}\text { integracja europejska, strefa euro, kryzys finansowy, stabilność } \\
\text { finansowa, nierównowagi makroekonomiczne, sektor finansowy, } \\
\text { polityka gospodarcza }\end{array}$ \\
\hline Keywords & $\begin{array}{l}\text { European integration, eurozone, financial crisis, financial stability, } \\
\text { macroeconomic imbalances, financial sector, economic policy }\end{array}$ \\
\hline O autorze & $\begin{array}{l}\text { profesor dr hab., Akademia Finansów i Biznesu Vistula • } \\
\text { worlowski@nobe.pl • ORCID 0000-0002-2320-2372 }\end{array}$ \\
\hline
\end{tabular}

Artykuł został udostępniony na licencji Creative Commons - Uznanie Autorstwa 3.0 Polska (CC BY 3.0 PL).

\section{Wstęp}

Unia Gospodarcza i Walutowa (UGiW), a więc wspólnota gospodarcza państw Unii Europejskiej (UE), w ramach której obowiązuje ścisła współpraca i koordynacja polityki gospodarczej, obejmuje dziś niemal wszystkie państwa członkowskie UE. Należy do niej zarówno 19 państw strefy euro, jak i siedem państw UE, które nie wprowadziły jeszcze wspólnej waluty euro, ale są do tego zobligowane traktatowo (po brexicie jedynie Dania nie jest do tego zobowiązana). Sytuacja państw, które nie są członkami strefy euro, jest nieco inna od położenia tych, które są w strefie - w szczególności nie dotyczy ich część ustaleń polityki gospodarczej obowiązujących w strefie euro ani nie stosuje się wobec nich najbardziej dolegliwych środków dyscyplinowania państw (np. kar finansowych za nieprzestrzeganie unijnych reguł) ${ }^{1}$. Rola strefy euro jako centrum gospodarczego UE wzrosła po brexicie, strefa euro obecnie wytwarza bowiem ponad 85\% całego unijnego PKB.

Od czasu wybuchu globalnego kryzysu finansowego, a następnie kryzysu zadłużeniowego strefy euro problemy stabilności finansowej Unii Europejskiej stały się przedmiotem zarówno licznych analiz naukowych, jak i intensywnych prac mających na celu wzmocnienie instytucji UE

1 J. Barcz, Reforma strefy euro Unii Europejskiej. Na drodze do sanacji i konsolidacji, Elipsa, Warszawa 2013, s. 32. 
odpowiedzialnych za stabilność. Następujące po sobie dwa kryzysy wywołały prawdziwy szok i w dramatyczny sposób odsłoniły ogromne słabości pierwotnej konstrukcji finansowej strefy euro ${ }^{2}$. Doprowadziło to do serii reform mających wzmocnić oraz poszerzyć instrumentarium Unii Gospodarczej i Walutowej. Reformy te w znacznej mierze już odmieniły funkcjonowanie zarówno strefy euro, jak i całej UE ${ }^{3}$. Otwarte jednak pozostaje pytanie, czy zmiany te były dostatecznie głębokie, by zapewnić stabilność finansową UE w przyszłości. Nie ma wątpliwości, że pewne fundamentalne dylematy pozostają nierozstrzygnięte, głównie z powodu trudności w uzyskaniu zgody politycznej co do kierunku zmian ${ }^{4}$. Efekty niektórych ważnych zmian z ostatniego okresu, w tym zwłaszcza wymuszonego przez pandemię COVID-19 utworzenia Instrumentu na rzecz Odbudowy i Zwiększania Odporności (The Recovery and Resilience Facility, RRF), nie są wcale jasne: nie wiadomo, czy jest to rzeczywiście "hamiltonowski moment" Europy (w nawiązaniu do porozumienia zawartego w 1790 r. w sprawie zaciągnięcia przez amerykański rząd federalny pożyczek i wsparcia odbudowy gospodarczej zrujnowanych wojną stanów, co ostatecznie doprowadziło do utworzenia wspólnych finansów publicznych i wspólnej polityki fiskalnej USA), czy przejściowe rozwiązanie, które nie będzie wywierać długotrwałego wpływu na sytuację w UE 5 .

Celem niniejszego artykułu jest przypomnienie wyzwań związanych ze stabilnością finansową UE, a następnie odpowiedź - na podstawie analizy danych - na pytanie, czy dokonane już reformy wystarczą do długookresowego ustabilizowania finansowego UE.

\section{U źródeł problemów: „grzech pierworodny"}

Kiedy w 1992 r. zaczął obowiązywać traktat z Maastricht, powszechnie zakładano, że przyjęte rozwiązania dają gwarancje stabilności finansowej całej Unii Europejskiej, a w szczególności strefie euro ${ }^{6}$. Stabilność finansowa miała być zapewniona przez spełnienie następujących warunków:

- Strefa euro miała stać się emitentem waluty światowej, która - jak uważano - mogła szybko zagrozić dolarowi będącemu główną walutą rezerwową świata (zasadniczym argumentem był fundamentalnie silniejszy - bliski równowagi - rachunek obrotów bieżących UE w porównaniu z chronicznym deficytem obrotów bieżących USA ${ }^{7}$ ).

2 R. Strauch, Lessons from the Euro Crisis, BBVA Seminar, Valencia, 23 January 2017, https://www.esm.europa. eu/speeches-and-presentations/lessons-euro-crisis [dostęp: 23 sierpnia 2021 r.], a także A. Mody, Eurotragedy: A Drama in Nine Acts, Oxford University Press, Oxford 2018, s. 7-8.

3 J. Barcz, op. cit., s. 15, a także J. Pisani-Ferry, Euro Area Reform: An Anatomy of the Debate , "CEPR Policy Insight" 2018, nr 75, https://cepr.org/sites/default/files/policy_insights/PolicyInsight95.pdf [dostęp: 23 sierpnia 2021 r.].

4 P. de Grauwe, The Economics of Monetary Integration, Oxford University Press, Oxford 1992, s. 118-119.

5 D. Zsolt et al., European Union Countries' Recovery and Resilience Plans, Bruegel Datasets, 9 June 2021, https:// www.bruegel.org/publications/datasets/european-union-countries-recovery-and-resilience-plans/ [dostęp: 21 czerwca $2021 \mathrm{r}$.].

6 P. de Grauwe, The Economics..., s. 70-72.

7 R. Mundell, The Euro and the Stability of the International Monetary System [w:] The Euro as a Stabilizer in the International Economic System, red. R. Mundell, A. Clesse, Springer, Boston 2000, s. 58. 
- Emisję wspólnej waluty miał prowadzić obdarzony pełną samodzielnością Europejski Bank Centralny (EBC), w przeciwieństwie do typowych banków centralnych wolny od nacisków politycznych na poziomie narodowym ${ }^{8}$.

- Jak powszechnie sądzono na początku lat 90. XX w., uzgodnione w Maastricht restrykcyjne warunki niezbędne do przystąpienia do strefy euro (kryteria konwergencji) miały spowodować, że w pierwszych latach jej funkcjonowania uczestniczyłyby w niej tylko stosunkowo nieliczne państwa „jądra” ówczesnej UE (w szczególności Niemcy, Francja i kraje Beneluksu; Wielka Brytania i Dania zagwarantowały sobie klauzulę opt-out, a kraje południa UE uważano za trwale niezdolne do spełnienia postawionych wymogów). Mimo istniejących różnic państwa „jądra" były przyzwyczajone do prowadzenia konserwatywnej polityki budżetowej (konwergencja zasad polityki finansowej Niemiec i Francji przypadła na lata 80. XX w.), cieszyły się wysoką wiarygodnością finansową, charakteryzowały się albo nadwyżką obrotów bieżących, albo ich równowagą, miały nieskrępowany dostęp do rynków finansowych i wysoko rozwinięty, stabilny sektor bankowy?

W szczególności ostatnie założenie miało wiele poważnych konsekwencji. Po pierwsze, bardzo ścisłe związki gospodarcze między przewidywanymi członkami strefy euro powodowały, że spełnione wydawały się warunki powstania optymalnego obszaru walutowego sformułowane przez R. Mundella (zwłaszcza kryterium wysokiej synchronizacji cykli koniunkturalnych i wysokiego stopnia integracji rynków pracy i kapitału $)^{10}$. Po drugie, zbliżone poziomy rozwoju tych państw i dojrzałości prowadzonej przez nie polityki dawały powody do przypuszczeń, że nie wystąpią poważniejsze problemy ani w odpowiednim dostosowaniu narodowych polityk fiskalnych, ani w mechanizmach dostosowania się do sytuacji gospodarczej przedsiębiorstw (w warunkach uczestnictwa we wspólnym obszarze walutowym dostosowania nominalne, tzn. dewaluacja waluty i kontrola podaży pieniądza, muszą być zastąpione dostosowaniami realnymi dokonywanymi na poziomie przedsiębiorstw, tzn. zmianami wydajności pracy, zatrudnienia i płac). Po trzecie, wysoki stopień rozwoju sektora bankowego i duże zdolności regulacyjne na poziomie narodowym pozwalały przypuszczać, że nie nastąpią poważne perturbacje w sektorze finansowym. Nie istniało zatem zauważalne ryzyko pojawienia się znaczących zaburzeń równowagi i stabilności finansowej, na które nie potrafiłaby odpowiedzieć polityka dostosowawcza na poziomie narodowym (makro) i na poziomie przedsiębiorstw (mikro).

Z przytoczonych powyżej założeń wynikały przyjęte rozwiązania instytucjonalne. Stworzono wprawdzie niezależny EBC, ale nie wyposażono go w uprawnienia pożyczkodawcy ostatniej instancji ani w stosunku do banków, ani rządów, a nadzór nad sektorem finansowym pozostawiono narodowym bankom centralnym. Nie ustalono wspólnych mechanizmów bankructwa i restrukturyzacji banków. Traktat z Maastricht koncentrował się na problemie deficytu i długu publicznego, został natomiast pominięty problem monitorowania sytuacji w zakresie finansów sektora prywatnego (zadłużenie, stabilność sektora bankowego). Skuteczne narzędzia kontroli polityki

8 P. de Grauwe, The Economics..., s. 156.

9 G. Thiemeyer, Economic Models in France and Germany and the Debates on the Maastricht Treaty, ,Journal of European Integration History" 2013, t. 19, nr 1, s. 85-103.

10 R. Mundell, A Theory of Optimal Currency Areas, „American Economic Review” 1961, nr 51, s. 657-666. 
fiskalnej wprowadzono początkowo głównie na etapie kwalifikacji do uczestnictwa w strefie euro (kryteria konwergencji), a nie po wejściu do tej strefy (mimo przyjęcia w 1997 r. zaostrzającego kontrolę Paktu Stabilności i Wzrostu dla członków strefy euro nadal nie istniał system automatycznych kar za łamanie reguł fiskalnych, a istniejące narzędzia dyscyplinujące nie były w praktyce wykorzystywane) ${ }^{11}$. Oczekiwane zasady prowadzenia polityki finansowej przez członków strefy euro powodowały nie tylko brak presji na ściślejszą koordynację polityki budżetowej, lecz także brak jasnych rozwiązań dotyczących ewentualnej restrukturyzacji długu publicznego tych państw strefy euro, którym groziłaby niewypłacalność. Zabrakło wreszcie zgody na zwiększenie budżetu UE w celu uzupełnienia mechanizmów rynkowych mechanizmami transferów fiskalnych, umożliwiających powrót do równowagi w przypadku wystąpienia szoku. Warto w tym miejscu przypomnieć, że w opublikowanym w 1977 r. raporcie MacDougalla ${ }^{12}$ (drugim, obok raportu Wernera z 1970 r.13 , kluczowym dokumencie koncepcyjnym dotyczącym powstania wspólnej waluty UE) stwierdzono, iż dla sprawnego funkcjonowania wspólnej waluty niezbędne jest posiadanie wspólnego budżetu na absolutnie minimalnym poziomie 2-2,5\% PKB (choć na dłuższą metę potrzebny byłby budżet na poziomie $5-7 \%$ PKB) ${ }^{14}$, a jak wiadomo, przez cały okres funkcjonowania UE nie udało się nigdy osiągnąć zgody na wzrost budżetu powyżej 1\% PKB ${ }^{15}$. Problemy w funkcjonowaniu wspólnej waluty, które mogą wynikać z braku dostatecznie rozbudowanych narzędzi wspólnej polityki fiskalnej, były dostrzegane jeszcze przed powstaniem strefy euro ${ }^{16}$.

Według ówczesnych oczekiwań kryteria uczestnictwa w strefie euro miały być spełnione w ciągu pierwszych kilku lat jej istnienia jedynie przez państwa, których sytuacja finansowa jest stabilna. Strefa euro miała więc się stać ostoją stabilności finansowej; zaburzenia równowagi mogły występować co najwyżej w państwach pozostających poza strefą w związku z prowadzoną przez nie polityką i nie miałyby charakteru zagrażającego stabilności całej UE (przykładem takich odizolowanych problemów, wymagających wsparcia bilansu płatniczego przez pozostałe państwa, ale nie rzutujących na sytuację całej wspólnoty, były doświadczenia Grecji z lat 80. XX w. ${ }^{17}$ ). Można się pokusić o stwierdzenie, że przewidywana konstrukcja finansowa UE miała w pewnej mierze przypominać system Bretton Woods: w centrum znajdowałaby się odporna na problemy strefa euro (zastępująca w tym miejscu Stany Zjednoczone), a kraje peryferyjne miałyby prowadzić politykę stabilizującą waluty wobec euro, przy czym w miarę potrzeb korzystałyby z finansowego wsparcia i dążyły do osiągnięcia, z czasem, stopnia stabilności umożliwiającego wejście do strefy.

11 A. Mody, op. cit., s. 221-224.

12 Commission of the European Communities, Report of the Study Group on the Role of Public Finance in European Integration, Brussels 1977, http://aei.pitt.edu/36433/1/Report.study.group.A13.pdf [dostęp: 26 sierpnia 2021 r.].

13 Commission of the European Communities, Report to the Council and the Commission on the Realization by Stages of Economic and Monetary Union in the Community, Luxembourg 1970, https://ec.europa.eu/archives/ emu_history/documentation/chapter5/19701008en72realisationbystage.pdf [dostęp: 26 sierpnia 2021 r.].

14 Commission of the European Communities, Report of the Study Group..., s. 69-70.

15 D. Gros, N. Thygesen, European Monetary Integration, Longman, London 1998, s. 152.

16 B.J. Eichengreen, J. Frieden, The Political Economy of European Monetary Unification: An Analytical Introduction, „Economics and Politics" 1993, t. 5, nr 2, s. 85-104.

17 D. Gros, N. Thygesen, op. cit., s. 72. 


\section{Zaskoczenie: strefa euro odmienna, niż oczekiwano}

Jak wiadomo, proces kwalifikacji państw do strefy euro przebiegł w sposób odmienny od tego, czego się powszechnie spodziewano. Zakładano bowiem, że kryteria konwergencji uniemożliwią akces krajom Południa (Włochom, Hiszpanii, Portugalii i Grecji) - miały o tym zadecydować wieloletnie przywiązanie do luźnej polityki fiskalnej (w tym zwłaszcza wysokie deficyty przykładowo we Włoszech w latach 80. XX w. deficyt finansów publicznych utrzymywał się na średnim poziomie ok. 11\% PKB), trwale wysokie oczekiwania inflacyjne i inflacja (we Włoszech na przełomie lat 80. i 90. ubiegłego wieku na poziomie ok. 7\%), a także brak zaufania rynków, prowadzący do wysokiego oprocentowania obligacji skarbowych (we Włoszech na przełomie lat 80. i 90. XX w. na poziomie ok. 13\%). W rzeczywistości wystąpiły jednak trzy zjawiska, których nie przewidywano ${ }^{18}$ :

- Spełnienie kryteriów fiskalnych okazało się dość kłopotliwe w państwach „jądra”, niegotowych do radykalnego dostosowania swojej polityki. Natomiast w krajach Południa, w powszechnym mniemaniu skazanych na pozostanie poza strefą euro, nastąpiła ogromna mobilizacja (popierana przez społeczeństwa) do wypracowania lub zwiększenia nadwyżki pierwotnej finansów publicznych.

- Na politykę mobilizacji rządów państw Południa pozytywnie odpowiedziały rynki finansowe, w efekcie czego nastąpił gwałtowny spadek oprocentowania obligacji skarbowych, a w ślad za tym - kosztów obsługi długu (co z kolei jeszcze silniej ograniczyło deficyty).

- Silny spadek deficytów, tworzący realną szansę na udział w strefie euro, spowodował równie gwałtowny spadek oczekiwań inflacyjnych.

Zjawiska te pozwoliły krajom Południa na spełnienie kryteriów konwergencji (por. wykres 1).

W efekcie tego, niespodziewanie, w 1999 r. kraje Południa (Włochy, Hiszpania i Portugalia, a z dwuletnim opóźnieniem również Grecja) dołączyły do strefy euro. Strefa wspólnej waluty ukształtowała się więc w formie zupełnie odmiennej od tej, którą zakładano, gdy ustalano jej architekturę instytucjonalną, a jej rozwój w latach 1999-2008 charakteryzował się narastaniem ogromnej nierównowagi makroekonomicznej. W krajach Południa pojawiły się silne deficyty obrotów bieżących, sięgające w 2008 r. od 9\% PKB w Hiszpanii do 14,6\% PKB w Grecji, którym towarzyszyły duże nadwyżki obrotów bieżących w krajach Północy (Niemcy, Holandia, Austria, Finlandia). Oznaczało to ogromny, niekontrolowany przepływ kapitału z krajów Północy do krajów Południa, głównie za pośrednictwem sektora bankowego. Towarzyszący temu zjawisku wzrost zadłużenia krajów Południa miał charakter niejednorodny: we wszystkich państwach z południa Europy nastąpił silny przyrost zadłużenia gospodarstw domowych (wzrost ten, w relacji do PKB, wyniósł od 18 p.p. PKB we Włoszech do 44 p.p. w Grecji) oraz przedsiębiorstw niefinansowych (wzrost od 23 p.p. PKB we Włoszech do 70 p.p. w Hiszpanii). Jednocześnie w Grecji i Portugalii silnie wzrosło zadłużenie rządu w relacji do PKB, ale we Włoszech i w Hiszpanii zadłużenie spadło (w Hiszpanii aż o 23 p.p. PKB) ${ }^{19}$. Napływowi kapitału i wzrostowi deficytów obrotów bieżących

18 W.M. Orłowski, Optymalna ścieżka do euro, Wydawnictwo Naukowe Scholar, Warszawa 2004, s. 107-111.

19 McKinsey Global Institute, Debt and (Not Much) Deleveraging, London-San Francisco-Shanghai 2015, https:// www.mckinsey.com/ /media/mckinsey/featured\%20insights/employment\%20and\%20growth/debt\%20 


\section{Wykres 1. Spełnienie przez kraje Południa kryteriów z Maastricht: przykład Włoch (lata 1991-1998)}

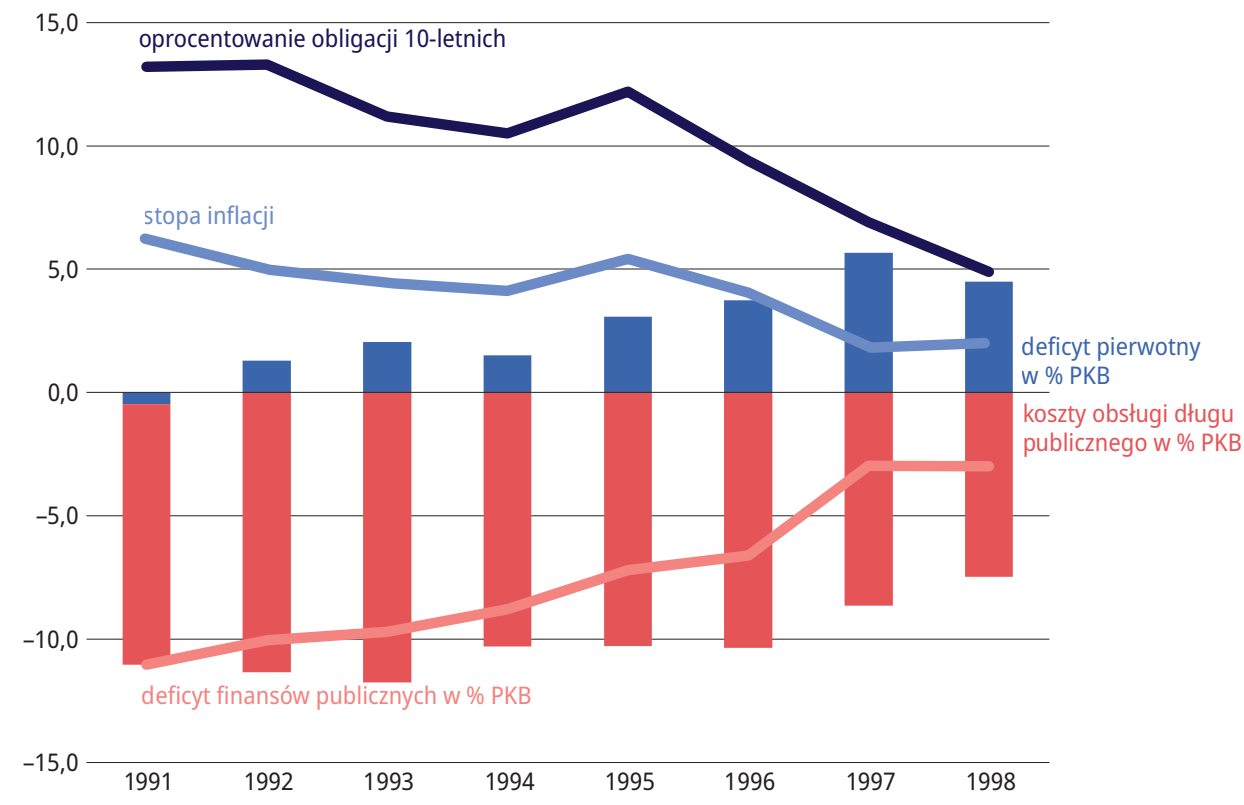

Źródło: Eurostat, https://ec.europa.eu/eurostat/web/main/data/database [dostęp: 31 sierpnia 2021 r.].

towarzyszyły, jako naturalna konsekwencja, realne wzmocnienie się waluty (przy braku zmian kursu walutowego, będącego konsekwencją używania euro, realizowało się ono przez szybszy wzrost płac nominalnych i cen w krajach Południa) i spadek konkurencyjności gospodarek.

Przyjęta konstrukcja instytucjonalna strefy euro nie pozwoliła na odpowiednią reakcję na rosnącą nierównowagę. Choć widać było zagrożenie, to w przypadku Hiszpanii (i w znacznym stopniu Włoch) nie wiązało się ono z łamaniem traktatowych zasad polityki fiskalnej, a w odniesieniu do łamiących te zasady Grecji i Portugalii UE nie sięgnęła po narzędzia dyscyplinujące z przyczyn politycznych (niechęci do karania Niemiec i Francji) ${ }^{20}$. Jednocześnie brak jasnych zasad współodpowiedzialności finansowej wszystkich członków strefy euro za długi zaciągane przez poszczególne państwa (brak mechanizmów bankructwa i restrukturyzacji) powodował, że na rosnącą nierównowagę nie reagowały rynki (w latach 1999-2007 oprocentowanie obligacji krajów Południa było stabilne i bliskie poziomu oprocentowania obligacji rządu Niemiec, a ich

and\%20not\%20much\%20deleveraging/mgi\%20debt\%20and\%20not\%20much\%20deleveragingfullreportfebruary2015.pdf [dostęp: 26 sierpnia 2021 r.].

20 A. Bénassy-Quéré, G. Wolff, How Has the Macro-Economic Imbalances Procedure Worked in Practice to Improve the Resilience of the Euro Area?, Brussels 2020, https://www.bruegel.org/wp-content/uploads/2020/03/ IPOL_STU2020645710_EN.pdf [dostęp: 25 sierpnia 2021 r.], s. 19-20. 
rating kredytowy pozostawał stabilny) ${ }^{21}$. "Grzech pierworodny" konstrukcji instytucjonalnej strefy euro doprowadził więc do braku skutecznych narzędzi koordynacji polityki gospodarczej oraz braku przeciwdziałania narastaniu nierównowagi (na poziomie całej gospodarki) w drodze polityki regulacyjnej, a także do zablokowania dyscyplinujących mechanizmów rynkowych, co z kolei prowadziło do bierności w obliczu rosnącego zagrożenia dla stabilności finansowej strefy euro wynikającego z niekontrolowanego zadłużania się krajów Południa.

\section{Kryzys i „piekielne sprzężenia”}

Pozorność stabilności finansowej strefy euro obnażył wybuch globalnego kryzysu finansowego, który szybko doprowadził do potężnej recesji i gwałtownego wzrostu deficytów finansów publicznych krajów Południa (w 2009 r. od 5,1\% PKB we Włoszech do 15,3\% w Grecji), wynikających po części z konieczności wsparcia sektora bankowego ${ }^{22}$.

Zjawiskiem szczególnie groźnym w czasie globalnego kryzysu finansowego okazało się wystąpienie w państwach strefy euro o słabszych finansach „piekielnych sprzężeń”. Pierwsze z nich było następujące: a) spadek zaufania rynków do rządu powodował wyprzedaż obligacji i wzrost stóp procentowych, pogarszający sytuację płynnościową rządu; b) inwestorzy za pieniądze ze sprzedaży obligacji kupowali aktywa z innych państw strefy euro, co powodowało kurczenie się krajowej podaży pieniądza; c) recesja i wzrost stóp procentowych sprawiły, że sytuacja finansowa rządu była coraz trudniejsza, co groziło zmianą kryzysu płynnościowego w kryzys zadłużeniowy (groźba niewypłacalności). Jak zauważa De Grauwe ${ }^{23}$, oznaczało to, że państwa strefy euro o słabszych finansach znalazły się w sytuacji typowej dla rynków wschodzących w tym sensie, iż zagrażał im typowy sudden stop (gwałtowne zatrzymanie napływu kapitału ${ }^{24}$ ), przy jednoczesnym braku narzędzia dewaluacji, które mogłoby osłabić ryzyko niewypłacalności, i przy braku zagwarantowanego wsparcia ze strony banku centralnego (EBC nie pełnił funkcji pożyczkodawcy ostatniej instancji, a narodowe banki nie mogły jej realizować, ponieważ nie emitowały waluty).

Drugim „piekielnym sprzężeniem” był związek trudnej sytuacji finansowej rządu z trudnym położeniem sektora bankowego ${ }^{25}$ : a) zagrożenie niewypłacalnością rządu powodowało spadek cen obligacji; b) spadek cen obligacji ujemnie wpływał na bilans banków krajowych, które zazwyczaj były głównymi inwestorami na rynku obligacji; c) wraz z recesją i ze spadkiem krajowej podaży pieniądza rosło ryzyko kryzysu bankowego, przy ograniczonych możliwościach wsparcia banków przez rząd.

Efektem recesji oraz wystąpienia dwóch „piekielnych sprzężeń” stało się to, że po kryzysie finansowym lat 2007-2009, wywołanym problemami sektora bankowego, w latach 2010-2012 na-

\footnotetext{
21 A. Mody, op. cit., s. 126.

22 R. Strauch, op. cit.

23 P. de Grauwe, The Governance of a Fragile Eurozone , „CEPS Working Document” 2011, nr 346, https://papers. ssrn.com/sol3/papers.cfm?abstract_id=1898618 [dostęp: 31 sierpnia 2021 r.], s. 3.

24 G. Calvo, Servicing the Public Debt: The Role of Expectations, „American Economic Review” 1988, t. 78, nr 4, s. 647-661.

25 P. de Grauwe, The Governance..., s. 5, a także J. Pisani-Ferry, op. cit., s. 4-5.
} 
stąpił gwałtowny spadek zaufania do wiarygodności finansowej krajów Południa: stopy oprocentowania obligacji rządowych wzrosły z poziomu 4,4-4,5\% w 2007 r. do 6-7\% we Włoszech i w Hiszpanii, 13\% w Portugalii i ponad 20\% w Grecji w końcu 2011 r. (w Niemczech spadły w tym czasie z 4,2\% do 1,9\%). W przypadku Grecji doprowadziło to do częściowego bankructwa państwa ${ }^{26}$. Jednocześnie okazało się, że strefie euro brakuje podstawowego instrumentarium do walki z kryzysem: nie istniały wspólne mechanizmy reakcji, jasne procedury restrukturyzacji i bankructwa, instytucje pełniące funkcję pożyczkodawcy ostatniej instancji (funkcji takiej nie obejmował mandat EBC, choć z czasem zaczął po części odgrywać taką rolę przez skup obligacji na rynku wtórnym), wspólne narzędzia służące udzielaniu pożyczek stabilizacyjnych dla zagrożonych niewypłacalnością rządów. Dopiero w trakcie kryzysu, w drodze trudnych i długotrwałych negocjacji, udało się w trybie awaryjnym stworzyć w 2010 r. Europejski Instrument Stabilności Finansowej (European Financial Stability Facility, EFSF), czyli fundusz dostarczający, we współpracy z Międzynarodowym Funduszem Walutowym (International Monetary Fund, IMF), warunkowego wsparcia finansowego zagrożonym niewypłacalnością gospodarkom strefy euro ${ }^{27}$, a także wypracować porozumienie w sprawie pakietu pomocowego i restrukturyzacji długu publicznego Grecji.

\section{Cztery podstawowe wyzwania i reformy z lat 2010-2020}

W czasie kryzysu zadłużeniowego lat 2010-2012 przed strefą euro i całą UE na nowo stanęło zadanie zmierzenia się z podstawowymi ułomnościami ich konstrukcji finansowej. Jak pokazano powyżej, problemy te nie zostały właściwie rozwiązane w czasie prac nad pierwotną strukturą strefy euro, czego konsekwencją był niezwykle ciężki przebieg kryzysów lat 2007-2009 i 2010 2012. Opinia ta, bardzo krytyczna w stosunku do przyjętych w przeszłości rozwiązań i będąca wezwaniem do dalszych intensywnych prac, jest podzielana zarówno przez zewnętrznych recenzentów, jak i przez głównych aktorów europejskiej sceny politycznej ${ }^{28}$.

Do wyzwań stojących przed UE należą:

- stworzenie skutecznych mechanizmów zapobiegania narastaniu nierównowagi ekonomicznej, związanej zarówno bezpośrednio z problemem nadmiernego zadłużenia państwa, jak i z problemem nadmiernego zadłużenia sektora prywatnego (oba te zjawiska stanowią zagrożenie dla stabilności sektora bankowego);

- wypracowanie trwałych mechanizmów stabilizacyjnych, służących rozwiązywaniu sytuacji kryzysowych;

- jednoznaczne ustalenie zakresu kompetencji i zadań EBC oraz innych instytucji unijnych w stosunku do sektora bankowego;

- uzupełnienie unii monetarnej o odpowiedni komponent fiskalny, zawierający rozwiązania zapewniające bezpieczne finansowanie polityki fiskalnej.

26 A. Mody, op. cit., s. 328.

27 European Stability Mechanism, Safeguarding The Euro in Times of Crisis: The Inside Story of the ESM, Publications Office of the European Union, Luxembourg 2019.

28 Por. tzw. raport pięciu prezydentów: J.C. Juncker, D. Tusk, J. Dijsselbloem, M. Draghi, M. Schulz, Completing Europe's Economic and Monetary Union, European Commission, Brussels 2015, s. 4-5. 
Pierwszemu wyzwaniu - przeciwdziałaniu narastaniu nierównowagi - można sprostać na różne sposoby lub przez zastosowanie odpowiedniej kombinacji różnych metod. Pierwszą z nich jest skuteczna koordynacja polityk gospodarczych, by zapewnić odpowiednio silną reakcję polityki gospodarczej (na poziomie całej UE / strefy euro lub na poziomie narodowym), wystarczającą do zahamowania i odwrócenia niebezpiecznych trendów. W obecnej sytuacji trudno sobie wyobrazić wprowadzenie wspólnej, jednolitej polityki gospodarczej - choćby w niektórych obszarach i ograniczonej do samej strefy euro (nie mówiąc o całej UE) - ze względu na opór polityczny przed takim rozwiązaniem (wyraźnie na to wskazują kluczowe wypowiedzi na temat przyszłości UE, w tym tzw. raport pięciu prezydentów ${ }^{29}$ oraz biała księga UE z 2017 r. $^{30}$ ). Dyskutowane są jednak propozycje utworzenia wspólnego budżetu strefy euro, powołania ministra finansów strefy euro, zapewniającego większą spójność w prowadzonych przez państwa członkowskie politykach gospodarczych, a także utworzenia filaru socjalnego UE (tzw. Europejskiej Unii Socjalnej) $)^{31}$. Wprowadzone w rzeczywistości zmiany dotyczące koordynacji polityki gospodarczej są znacznie skromniejsze od założeń. W ramach tzw. dwupaku i sześciopaku wdrożono działania służące lepszemu raportowaniu sytuacji oraz wzmocnieniu wspólnej kontroli nad polityką fiskalną poszczególnych państw i nad równowagą makroekonomiczną (w tym Semestr Europejski, a więc procedurę pozwalającą na ocenę przez instytucje unijne planów budżetowych poszczególnych państw, i procedurę zakłóceń równowagi makroekonomicznej, rozciągającą kontrolę na różne obszary finansów publicznych i prywatnych). Według często głoszonych ocen wprowadzone reformy nie stanowią prawdziwego przełomu, głównie z powodu braku politycznej zgody na stosowanie silniejszych narzędzi dyscyplinujących ${ }^{32}$. Zwraca się też uwagę, że wdrożone rozwiązania nakierowane są jedynie na rozwiązanie problemu nadmiernych deficytów, a pomijają - również ważny dla zwalczania nierównowagi makroekonomicznej - problem zachęt do redukcji dużych nadwyżek ${ }^{33}$.

Drugiemu wyzwaniu, polegającemu na stworzeniu trwałych mechanizmów stabilizacyjnych, starano się sprostać przez stworzenie EFSF, przekształconego później w Europejski Mechanizm Stabilności (European Stability Mechanism, ESM), działający we współpracy z IMF i finansowany ze środków zebranych z rynku w oparciu o kapitał dostarczony przez państwa strefy euro. W sferze projektów pozostaje jednak nadal przekształcenie ESM w „europejski IMF”, a więc instytucję znacznie mniej podatną na naciski polityczne i z mocniejszym mandatem do negocjowania i egzekwowania niezbędnych dostosowań polityki gospodarczej w państwach borykających się

29 Ibidem, s. 13-15.

30 European Commission, White Paper on the Future of Europe: Reflections and Scenarios for the EU27 by 2025, Brussels 2017, https://ec.europa.eu/commission/sites/beta-political/files/white_paper_on_the_future_of_ europe_en.pdf [dostęp: 25 sierpnia 2021 r.], s. 26-27.

31 F. Vandenbroucke, Why We Need a European Social Union, "Reflets et Perspectives de la Vie Economique” 2013, t. 52, nr 2/3, s. 97-112.

32 S. Eckert, V. Lindner, A. Nölke, EMU Reform Proposals and Their (non) Implementation: An Overview, "SAFE White Paper" 2021, nr 78, https://www.econstor.eu/bitstream/10419/228535/1/1743908407.pdf [dostęp: 25 sierpnia 2021 r.], s. 22.

33 A. Bénassy-Quéré, G. Wolff, op. cit., s. 10. 
z kłopotami finansowymi ${ }^{34}$. Tego typu kroki powinny zmniejszyć koszty gospodarcze i społeczne działań dostosowawczych, które wciąż są prowadzone głównie za pomocą narzędzi wewnętrznej dewaluacji (ograniczenia płac i cen w wyniku recesji).

Trzeciemu wyzwaniu, a zatem określeniu roli EBC i polityki regulacyjnej wobec sektora bankowego, stawiono czoła przez wprowadzenie rozwiązań Europejskiej Unii Bankowej, a więc uwspólnotowienie nadzoru nad bankami ważnymi systemowo i ustanowienie wspólnego mechanizmu restrukturyzacji i uporządkowanej likwidacji banków. Dotychczas nie udało się jednak utworzyć wspólnego mechanizmu gwarantowania depozytów, a cały system działa jako sieć współpracujących instytucji narodowych ${ }^{35}$. Należy też dodać, że dopiero groźba poważnych problemów wywołana kryzysem pandemicznym wymusiła zgodę na ewentualne awaryjne wsparcie ze środków ESM funduszu finansowania restrukturyzacji i uporządkowanej likwidacji banków. W sytuacji tej wyraźnie wzrosła również rola i odpowiedzialność EBC za stabilność finansową państw strefy euro. Wobec silnych oporów natury politycznej nie jest jednak jasne, czy zwiększona skłonność EBC do prowadzenia niekonwencjonalnej polityki pieniężnej i do pełnienia (w pewnej mierze) funkcji pożyczkodawcy ostatniej instancji wobec rządów będzie zjawiskiem trwałym ${ }^{36}$.

Czwarte wyzwanie, a więc stworzenie komponentu fiskalnego UGiW, jest prawdopodobnie najpoważniejsze spośród tych, które od początku stały przed UE i strefą euro. Od rozpoczęcia dyskusji nad utworzeniem obszaru wspólnej waluty było jasne, że poważne zwiększenie skali transferów wewnątrz UE (i tym samym unijnego budżetu) jest rozwiązaniem, które pozwoliłoby znacznie zbliżyć strefę euro do spełnienia wymogów optymalnego obszaru walutowego i zapewniało odpowiednią reakcję polityki gospodarczej na szoki asymetryczne. Jednocześnie jednak takie działanie wywoływało od początku silny opór części państw na czele z Niemcami ${ }^{37}$, niegodzących się na znaczny wzrost skali budżetu. Sytuacja nie zmieniła się do dziś, choć według niektórych ocen zgoda na uruchomienie funduszu $\mathrm{RRF}^{38}$ może zwiastować przełom w myśleniu o aktywnej roli UE w dziedzinie fiskalnej (nie jest to jednak wcale pewne, bo RRF może mieć charakter wyjątkowy i jednorazowy). Utworzenie RRF, finansowanego ze środków zebranych na rynku przez UE na podstawie wspólnych gwarancji państw członkowskich, może natomiast stanowić ważny precedens w kwestii współodpowiedzialności za dług (uwspólnotowienia długu publicznego). Jest to także rozwiązanie kontrowersyjne, ponieważ stwarza pokusę nadużycia, a więc prowadzenia nieodpowiedzialnej polityki fiskalnej lub unikania wprowadzenia niezbęd-

34 European Parliament, The ESM and the IMF: Comparison of the Main Features, Brussels 2018, https://www. europarl.europa.eu/RegData/etudes/IDAN/2017/614485/IPOL_IDA(2017)614485_EN.pdf [dostęp: 23 sierpnia 2021 r.], s. 5.

35 S. Eckert, V. Lindner, A. Nölke, op. cit., s. 7-8.

36 I. Schnabel, The Shadow of Fiscal Dominance: Misconceptions, Perceptions and Perspectives, wystąpienia na Eurofi Financial Forum, Berlin 2020, https://www.ecb.europa.eu/press/key/date/2020/html/ecb. sp200911 ea32bd8bb3.en.html [dostęp: 25 sierpnia 2021 r.].

37 D. Gros, N. Thygesen, op. cit., s. 12.

38 European Commission, Next Generation EU: Commission Presents Next Steps for €672.5 Billion Recovery and Resilience Facility in 2021 Annual Sustainable Growth Strategy, Brussels 2020, https://ec.europa.eu/commission/presscorner/detail/en/IP_20_1658 [dostęp: 25 sierpnia 2021 r.]. 
nego programu dostosowawczego ${ }^{39}$. Mimo sformułowania różnorodnych propozycji częściowego uwspólnotowienia długu (głównie przez emisję wspólnych obligacji pokrywających część długu publicznego państw członkowskich - np. do poziomu $60 \% \mathrm{PKB}^{40}$ ) projekt wydaje się mało realistyczny, z wyjątkiem wspólnych obligacji służących sfinansowaniu RRF (czyli jednorazowej operacji walki z efektami pandemii).

\section{Czy są potrzebne kolejne reformy?}

Najtrudniejsze pytanie brzmi: Czy przeprowadzone do tej pory reformy wystarczą do tego, by długookresowo zapewnić stabilność finansową strefy euro i całej UE? Aby spróbować udzielić na nie odpowiedzi, należy przyjrzeć się dotychczasowym efektom wprowadzonych reform w różnych obszarach funkcjonowania gospodarki i polityki gospodarczej UE ${ }^{41}$.

Pierwszy problem dotyczy skuteczności koordynacji polityk gospodarczych państw UE w odniesieniu do finansów publicznych, co jest warunkiem realizacji odpowiedniej, spójnej polityki makroekonomicznej (policy mix) ${ }^{42}$. Efekty dotychczasowych działań przedstawia wykres 2. Jak widać, w wyniku załamania spowodowanego kryzysem finansowym w latach 2009-2010 traktatowe kryterium deficytu (poniżej 3\% PKB) było spełnione przez zaledwie sześć państw UE, a kryterium długu publicznego (poziom poniżej 60\% PKB lub zadowalające tempo spadku tej relacji, jeśli przekracza 60\%) spełniało 17 państw, w 2013 r. - tylko 14. Zastosowane ostrzejsze środki dyscyplinujące i warunkowość narzucona w ramach ESM, wsparte przez presję ze strony rynku, doprowadziły więc do radykalnej poprawy sytuacji mimo utrzymującej się w wielu państwach sytuacji recesyjnej lub deflacyjnej ${ }^{43}$. W 2019 r. kryterium deficytu spełniały już wszystkie państwa UE-27 poza Rumunią, a kryterium długu - 23 (na 11 państw o relacji długu do PKB powyżej 60\% w siedmiu nastąpił zadowalający spadek długu).

Prawdziwym testem dla przyjętych rozwiązań będą jednak nadchodzące lata. Kryzys COVID-19 spowodował, że w 2020 r. żadne państwo UE nie spełniało kryterium deficytu, a relacja długu publicznego do PKB wzrosła od 2 p.p. w Irlandii do 28 p.p. w Grecji. Lata popandemiczne pokażą, jak szybko uda się poprawić tę sytuację.

Kolejny problem dotyczy sposobów odzyskiwania równowagi po wstrząsie gospodarczym. W latach 2009-2019 udało się to osiągnąć głównie dzięki bolesnej, wymuszonej groźbą niewypłacalności, rozłożonej na lata wewnętrznej dewaluacji w krajach Południa, wspartej przez pożyczki płynnościowe z EBC i programy stabilizacyjne uzgodnione w ramach ESM ${ }^{44}$. Przeprowadzona ścieżka dostosowania uważana jest często za mało efektywną i zbyt kosztowną ${ }^{45}$. Co

39 I. Schnabel, op. cit.

40 J. Pisani-Ferry, op. cit., s. 7-8.

41 Bieżący stan zaawansowania reform szczegółowo przedstawia praca S. Eckert, V. Lindner, A. Nölke, op. cit.

42 E. Bartsch, A. Bénassy-Quéré, G. Corsetti, X. Debrun, It's All in the Mix: How Monetary and Fiscal Policies Can Work or Fail Together, "Geneva Reports on the World Economy" 2020, nr 23, s. 4-5.

43 A. Bénassy-Quéré, G. Wolff, op. cit., s. 14-17.

44 R. Strauch, op. cit.

45 A. Mody, op. cit., s. 411-412. 


\section{Wykres 2. Liczba państw UE-27 spełniających kryteria fiskalne traktatu z Maastricht w latach 2000-2020}

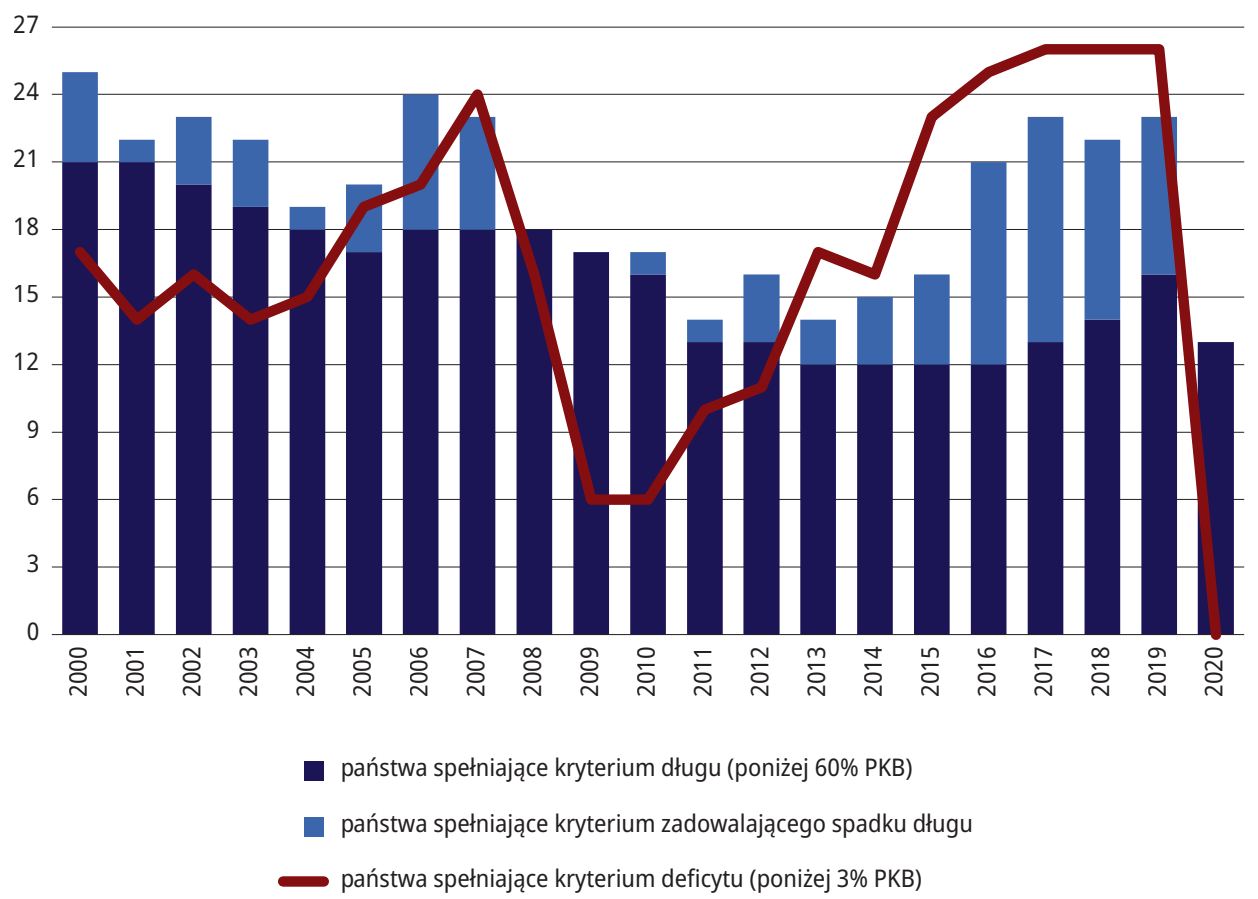

Źródło: obliczenia własne na podstawie danych International Monetary Fund, World Economic Outlook Database, https://www.imf.org/en/Publications/WEO/weo-database/2021/April [dostęp: 31 sierpnia 2021 r.].

więcej, wprowadzone rozwiązania i mechanizmy stabilizacyjne umożliwiły redukcję deficytów obrotów bieżących w krajach Południa (głównie w wyniku długotrwałej recesji lub stagnacji, podtrzymanej przez programy konsolidacji fiskalnej), nie rozwiązały jednak problemu znacznych nadwyżek obrotów bieżących w krajach Północy (wykres 3). Instytucje odpowiedzialne za zwalczanie nierównowagi powinny więc zostać wzmocnione, być może według modelu IMF, a także wyposażone w narzędzia pozwalające oddziaływać na politykę nie tylko państw, którym zagraża niewypłacalność, lecz także tych generujących duże nadwyżki obrotów bieżących.

Kolejny ważny problem to sytuacja sektora bankowego i dążenie do uniknięcia nadmiernego boomu kredytowego w sektorze prywatnym. Dane o poziomie zadłużenia sektora prywatnego (głównie w krajowych bankach) i zmianach tego poziomu przedstawiono w tabeli 1.

Przytoczone dane pozwalają śledzić zarówno narastanie nadmiernego zadłużenia sektora prywatnego w UE-27 przed wybuchem kryzysu finansowego (1999-2008), jak i proces globalnego delewarowania w latach 2008-2014 oraz ponownego wzrostu kredytu dla sektora prywatnego w latach 2014-202046. Jak można zauważyć, przyrost zadłużenia gospodarstw domowych

46 McKinsey Global Institute, op. cit., s. 3-5. 
Wykres 3. Kryzys i przywrócenie równowagi finansowej krajów Południa* w latach 1999-2020

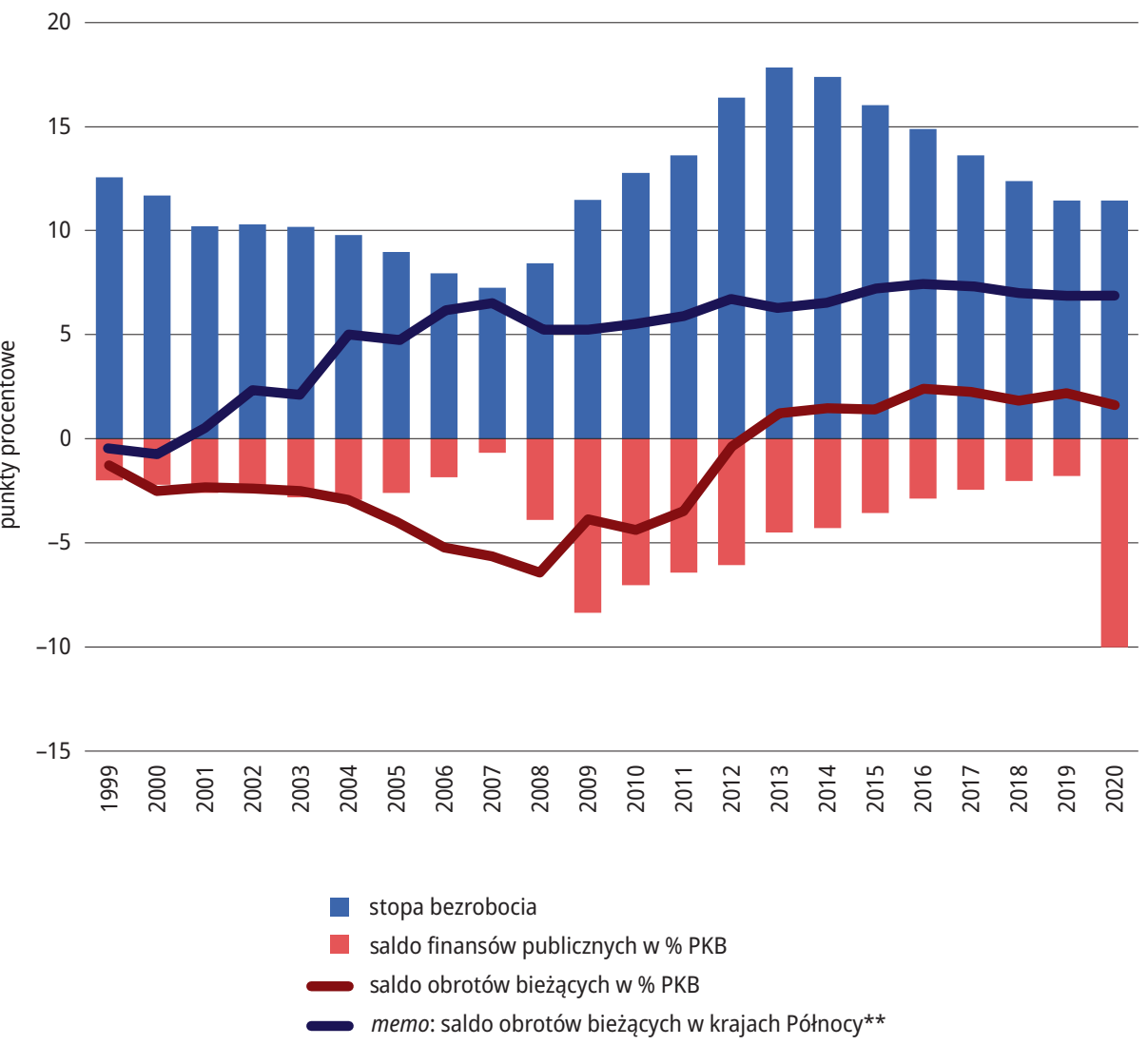

* kraje Południa: Włochy, Hiszpania, Portugalia, Grecja, Cypr (średnia ważona PKB według bieżących kursów walut) ** kraje Północy: Niemcy, Holandia, Austria, Finlandia (średnia ważona PKB według bieżących kursów walut) Źródło: obliczenia własne na podstawie danych International Monetary Fund, op. cit.

i przedsiębiorstw był w latach 1999-2008 szczególnie silny w krajach Południa (szybszy niż w USA i Wielkiej Brytanii), a także w państwach o specyficznym systemie bankowym, wykorzystującym do rozwoju efekty globalizacji (Irlandia, Luksemburg). Kraje Północy zachowywały dużą wstrzemięźliwość i nie dopuściły do boomu kredytowego. W wyniku tych zmian zadłużenie gospodarstw domowych nie sięgnęło w państwach UE-27 poziomu anglosaskiego, ale w odniesieniu do zadłużenia przedsiębiorstw go przekroczyło (co można tłumaczyć większą rolą giełdy w finansowaniu przedsiębiorstw w krajach anglosaskich) ${ }^{47}$.

47 OECD, Role of Banks, Equity Markets and Institutional Investors in Long-Term Financing for Growth and Development. Report for G20 Leaders, Paris 2013, https://www.oecd.org/finance/private-pensions/G20reportLTFinancingForGrowthRussianPresidency2013.pdf [dostęp: 25 sierpnia 2021 r.], s. 7. 
Tabela 1. Poziom i zmiany poziomu zadłużenia sektora prywatnego jako \% PKB* w latach 1999-2020

\begin{tabular}{|c|c|c|c|c|c|c|c|c|}
\hline & \multicolumn{8}{|c|}{ Poziom zadłużenia } \\
\hline & \multicolumn{4}{|c|}{ gospodarstwa domowe } & \multicolumn{4}{|c|}{ przedsiębiorstwa niefinansowe } \\
\hline & 1999 & 2008 & 2014 & 2020 & 1999 & 2008 & 2014 & 2020 \\
\hline Strefa euro (Euro-19) & 47 & 61 & 60 & 62 & 78 & 100 & 105 & 115 \\
\hline \multicolumn{9}{|l|}{ w tym: } \\
\hline - kraje Południaa & 29 & 58 & 57 & 53 & 57 & 98 & 95 & 88 \\
\hline - kraje Północy & 69 & 68 & 64 & 67 & 79 & 84 & 87 & 91 \\
\hline - kraje pozostałe & 34 & 53 & 58 & 65 & 101 & 127 & 144 & 176 \\
\hline Kraje poza strefą euro ${ }^{d}$ & 38 & 56 & 61 & 60 & 69 & 92 & 95 & 97 \\
\hline Unia Europejska razeme & 46 & 60 & 60 & 62 & 77 & 99 & 104 & 112 \\
\hline \multicolumn{9}{|l|}{ Zróżnicowanie w UE-27e } \\
\hline - poziom najniższy & $\begin{array}{c}1 \\
\text { Rumunia }\end{array}$ & $\begin{array}{c}19 \\
\text { Rumunia }\end{array}$ & $\begin{array}{c}19 \\
\text { Rumunia }\end{array}$ & $\begin{array}{c}20 \\
\text { Rumunia }\end{array}$ & $\begin{array}{c}28 \\
\text { Rumunia }\end{array}$ & $\begin{array}{c}40 \\
\text { Polska }\end{array}$ & $\begin{array}{c}47 \\
\text { Polska }\end{array}$ & $\begin{array}{c}46 \\
\text { Polska }\end{array}$ \\
\hline - poziom najwyższy & $\begin{array}{c}87 \\
\text { Holandia }\end{array}$ & $\begin{array}{l}127 \\
\text { Dania }\end{array}$ & $\begin{array}{c}124 \\
\text { Dania }\end{array}$ & $\begin{array}{l}112 \\
\text { Holandia }\end{array}$ & $\begin{array}{c}128 \\
\text { Irlandia }\end{array}$ & $\begin{array}{l}271 \\
\text { Luksemburg }\end{array}$ & $\begin{array}{c}338 \\
\text { Luksemburg }\end{array}$ & $\begin{array}{c}342 \\
\text { Luksemburg }\end{array}$ \\
\hline \multicolumn{9}{|l|}{ Memo: } \\
\hline Wielka Brytania & 62 & 94 & 85 & 90 & 66 & 92 & 73 & 80 \\
\hline \multirow[t]{4}{*}{ USA } & 69 & 96 & 79 & 80 & 63 & 73 & 69 & 85 \\
\hline & \multicolumn{8}{|c|}{ Zmiana poziomu zadłużenia (p.p. PKB) } \\
\hline & \multicolumn{4}{|c|}{ gospodarstwa domowe } & \multicolumn{4}{|c|}{ przedsiębiorstwa niefinansowe } \\
\hline & & $\begin{array}{l}2008 / \\
/ 1999\end{array}$ & $\begin{array}{l}2014 / \\
/ 2008\end{array}$ & $\begin{array}{l}2020 / \\
/ 2014\end{array}$ & & $\begin{array}{l}2008 / \\
/ 1999\end{array}$ & $\begin{array}{l}2014 / \\
/ 2008\end{array}$ & $\begin{array}{l}2020 / \\
/ 2014\end{array}$ \\
\hline Strefa euro (Euro-19) & & 13 & -1 & 2 & & 23 & 5 & 9 \\
\hline \multicolumn{9}{|l|}{ w tym: } \\
\hline - kraje Południa & & 30 & -2 & -3 & & 41 & -3 & -7 \\
\hline - kraje Północy & & -2 & -4 & 2 & & 6 & 2 & 4 \\
\hline - kraje pozostałe & & 19 & 5 & 7 & & 26 & 17 & 32 \\
\hline Kraje poza strefą euro ${ }^{d}$ & & 18 & 6 & -1 & & 23 & 3 & 2 \\
\hline Unia Europejska razeme & & 14 & 0 & 2 & & 23 & 5 & 8 \\
\hline \multicolumn{9}{|l|}{ Zróżnicowanie w UE-27e } \\
\hline - wzrost najniższy & & $\begin{array}{l}-11 \\
\text { Niemcy }\end{array}$ & $\begin{array}{c}-27 \\
\text { Irlandia }\end{array}$ & $\begin{array}{l}-45 \\
\text { Irlandia }\end{array}$ & & $\begin{array}{c}-18 \\
\text { Czechy }\end{array}$ & $\begin{array}{c}-39 \\
\text { Rumunia }\end{array}$ & $\begin{array}{l}-40 \\
\text { Irlandia }\end{array}$ \\
\hline - wzrost najwyższy & & $\begin{array}{c}103 \\
\text { Irlandia }\end{array}$ & $\begin{array}{c}14 \\
\text { Szwecja }\end{array}$ & $\begin{array}{c}13 \\
\text { Francja }\end{array}$ & & $\begin{array}{c}184 \\
\text { Luksemburg }\end{array}$ & $\begin{array}{c}67 \\
\text { Luksemburg }\end{array}$ & $\begin{array}{c}40 \\
\text { Francja }\end{array}$ \\
\hline \multicolumn{9}{|l|}{ Memo: } \\
\hline Wielka Brytania & & 33 & -9 & 5 & & 26 & -18 & 7 \\
\hline USA & & 27 & -17 & 0 & & 10 & -4 & 16 \\
\hline
\end{tabular}

* średnie ważone wielkością PKB państw według bieżących kursów walut

a kraje Południa: Włochy, Hiszpania, Portugalia i Grecja

b kraje Północy: Niemcy, Holandia, Austria i Finlandia

c bez Estonii, Litwy, Łotwy, Cypru, Malty, Słowacji i Słowenii 


\begin{abstract}
${ }^{d}$ bez Bułgarii i Chorwacji
e bez wymieniowych w pkt c id

Źródło: obliczenia własne na podstawie danych: Bank for International Settlements, About Credit Statistics, https://www.bis.org/statistics/about_credit_stats.htm?m=6\%7C380 [dostęp: 31 sierpnia 2021 r.] oraz McKinsey Global Institute, Visualizing Global Debt, https://www.mckinsey.com/business-functions/strategy-and-corporate-finance/our-insights/visualizing-global-debt [dostęp: 31 sierpnia 2021 r.].
\end{abstract}

W latach delewarowania (2008-2014) w skali całej UE-27, a także w grupach krajów Południa i Północy zaszły tylko nieznaczne zmiany poziomu zadłużenia sektora prywatnego (w odróżnieniu od krajów anglosaskich). Podobne spostrzeżenie można sformułować w przypadku zmian poziomu zadłużenia sektora prywatnego w latach 2014-2020: zadłużenie to lekko spadło w krajach Południa, lekko wzrosło w krajach Północy, ale silnie wzrosło w pozostałych państwach, głównie wskutek silnego wzrostu odnotowanego we Francji. Wzrost zadłużenia korporacyjnego we Francji do poziomu 171\% PKB powinien niepokoić, zwłaszcza w sytuacji słabych wyników w zakresie wzrostu PKB; nie doczekał się on jednak żadnej znaczącej reakcji ze strony instytucji unijnych. Reformy w tym zakresie nie doprowadziły jeszcze do powstania odpowiednio silnych mechanizmów ostrzegawczych.

Inną metodą oceny sytuacji w sektorze bankowym są wyniki stress testów, dokonywanych systematycznie przez Europejski Urząd Nadzoru Bankowego (European Banking Authority, EBA). Celem prowadzonych symulacji jest ustalenie, w jaki sposób zmieniłyby się współczynniki kapitałowe systemowo ważnych banków europejskich w przypadku gwałtownego pogorszenia się sytuacji gospodarczej. Powszechnie używaną miarą sytuacji banków jest relacja wysoce płynnych kapitałów własnych (tzw. kapitału podstawowego Tier 1) do aktywów. Jak uznano, spadek tej relacji poniżej 4,5\% oznacza zagrożenie, że w obliczu nieoczekiwanych strat bank może stać się niewypłacalny ${ }^{48}$. Wyniki stress testów przeprowadzonych w latach 2010 i 2018 na grupie największych banków europejskich, pogrupowane według państw (w niektórych z nich, w tym w Polsce, badaniem był objęty tylko jeden bank), przedstawia wykres 4.

Gdy analizuje się wyniki, nasuwają się dwa spostrzeżenia. Po pierwsze, europejski sektor bankowy jest dziś lepiej niż przed dekadą przygotowany do radzenia sobie z sytuacjami kryzysowymi (w szczególności poprawa nastąpiła w największych gospodarkach UE-27). Po drugie, sytuacja w poszczególnych państwach jest bardzo zróżnicowana, a instytucje z trzech państw o najsłabszych systemach bankowych w 2010 r. w ogóle nie zostały objęte stress testami w 2018 r. Niezależnie od osiągniętego postępu nadzór nad sektorem bankowym wymaga dalszego wzmocnienia, zwłaszcza wobec braku jednolitego systemu gwarantowania depozytów, który mógłby zapobiec wybuchom paniki bankowej w poszczególnych państwach (jak to było np. w Grecji w 2012 r.).

Kolejnym elementem oceny skuteczności wprowadzonych reform jest sytuacja na rynku nieruchomości. Zmiany cen nieruchomości stanowią jeden z elementów wprowadzonej w 2011 r.

48 European Banking Authority, 2018 EU-wide Stress Test: Result, London 2018, https://www.eba.europa.eu/ sites/default/documents/files/documents/10180/2419200/126521e6-613f-45e4-af84-cbd3b854afc5/2018-EU-wide-stress-test-Results.pdf?retry=1 [dostęp: 26 sierpnia 2021 r.], s. 8. 


\section{Wykres 4. Ocena sytuacji banków w państwach UE* na podstawie stress testów EBA (relacja kapitału podstawowego Tier 1 do aktywów po dwóch latach)}

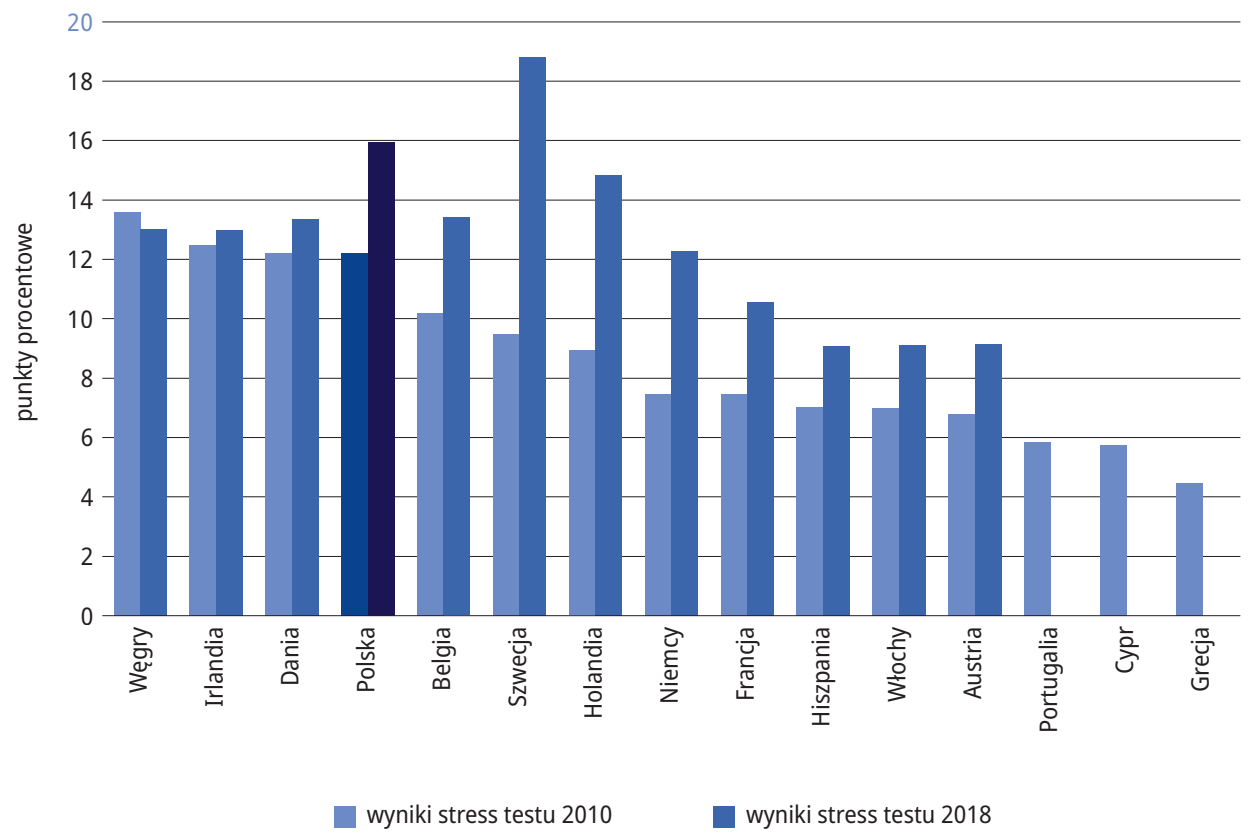

* wynik obliczony jako średnia arytmetyczna wyników banków z danego państwa

Źródło: obliczenia własne na podstawie danych: European Banking Authority, 2018 EU-wide Stress Test: Result, London 2018, https://www.eba.europa.eu/sites/default/documents/files/documents/10180/2419200/126521 e6-613f-45e4-af84-cbd3b854afc5/2018-EU-wide-stress-test-Results.pdf?retry=1 [dostęp: 26 sierpnia 2021 r.], s. 49-58 oraz Committee of European Banking Supervisors, Aggregate Outcome of the 2010 EU wide Stress Test Exercise Coordinated by CEBS in Cooperation with the ECB, 2010, https://www.eba.europa.eu/sites/default/documents/files/documents/10180/15938/95030af2-7b52-4530-afe1-f067a895d163/Summaryreport.pdf?retry=1 [dostęp: 31 sierpnia 2021 r.].

oceny nierównowagi makroekonomicznej w państwach UE: jak uczy doświadczenie, zwłaszcza kryzysu lat 2007-2009, bańki spekulacyjne na tym rynku mogą prowadzić do ogromnych kłopotów gospodarczych ${ }^{49}$. Tabela 2 przedstawia dane o kształtowaniu się cen nieruchomości w okresie 2007-2020. Załamanie tych cen w latach 2007-2014 doprowadziło do ich spadku w krajach Południa o 30\%, przy niemal niezmienionym poziomie w krajach Północy (najsilniejszy spadek w UE-27 odnotowała Irlandia, największy wzrost - Szwecja). W latach 2014-2020, kiedy rynek nieruchomości był już elementem oceny równowagi finansowej, w krajach Południa nastąpił jedynie nieznaczny wzrost cen. Stosunkowo silny wzrost wystąpił natomiast w krajach Północy oraz w niektórych państwach poza strefą euro. Łącznie w 2020 r. poziom cen nieruchomości

49 A. Mody, op. cit., s. 411. 
w całej UE-27 był zbliżony do poziomu z 2007 r., co wygląda względnie bezpiecznie. Najwyższy łączny wzrost cen odnotowany w Szwecji (o 56\%), a także w Austrii (o 46\%) może jednak już wzbudzać zaniepokojenie.

\section{Tabela 2. Realne zmiany cen nieruchomości w państwach UE* w latach 2007-2020 (zdeflowane wskaźnikiem inflacji)}

\begin{tabular}{|c|c|c|c|}
\hline & $2014 / 2007$ & $2020 / 2014$ & Łącznie $2020 / 2007$ \\
\hline Strefa euro (Euro-19) & $-13 \%$ & $16 \%$ & $0 \%$ \\
\hline \multicolumn{4}{|l|}{ w tym: } \\
\hline - kraje Południa & $-30 \%$ & $6 \%$ & $-26 \%$ \\
\hline - kraje Północy & $-1 \%$ & $26 \%$ & $25 \%$ \\
\hline - kraje pozostałe & $-13 \%$ & $11 \%$ & $-3 \%$ \\
\hline Poza strefą euro & $-12 \%$ & $26 \%$ & $11 \%$ \\
\hline Unia Europejska razem (UE-27) & $-13 \%$ & $17 \%$ & $2 \%$ \\
\hline \multicolumn{4}{|l|}{ Zróżnicowanie w UE-27 } \\
\hline - wzrost najniższy & $\begin{array}{c}-47 \% \\
\text { Irlandia }\end{array}$ & $\begin{array}{c}-8 \% \\
\text { Włochy }\end{array}$ & $\begin{array}{l}-43 \% \\
\text { Grecja }\end{array}$ \\
\hline - wzrost najwyższy & $\begin{array}{c}25 \% \\
\text { Szwecja }\end{array}$ & $\begin{array}{c}76 \% \\
\text { Węgry }\end{array}$ & $\begin{array}{c}56 \% \\
\text { Szwecja }\end{array}$ \\
\hline \multicolumn{4}{|l|}{ Memo: } \\
\hline Wielka Brytania & $-17 \%$ & $14 \%$ & $-5 \%$ \\
\hline USA & $-21 \%$ & $19 \%$ & $-6 \%$ \\
\hline
\end{tabular}

* średnie ważone wielkością PKB państw według bieżących kursów walut

a kraje Południa: Włochy, Hiszpania, Portugalia, Grecja

b kraje Północy: Niemcy, Holandia, Austria, Finlandia

Źródło: obliczenia własne na podstawie danych Bank for International Settlements, Residential Property Prices: Detailed Series (Nominal), 2021, https://www.bis.org/statistics/pp_detailed.htm?m=6\%7C288\%7C593 [dostęp: 31 sierpnia 2021 r.].

\section{Wnioski}

Można stwierdzić, że szok spowodowany podwójnym kryzysem lat 2007-2009 i 2010-2012 zaowocował znacznymi zmianami mechanizmów zapewniających stabilność finansową strefy euro i całej UE. Państwa członkowskie i instytucje unijne podjęły wiele działań mających na celu wyeliminowanie słabości zidentyfikowanych w konstrukcji strefy euro i naprawienie błędów, które doprowadziły do sytuacji kryzysowej. Obecny szok związany z pandemią COVID-19 wymusił podjęcie kolejnych trudnych decyzji. W ten sposób być może zostały rozstrzygnięte ciągnące się od dekad spory, a w wielu dziedzinach przełamany długookresowy opór przed pogłębieniem integracji. Program reform wprowadzony w latach 2010-2020, a kontynuowany obecnie, wraz z historyczną decyzją o uruchomieniu funduszu RRF, w znacznym stopniu zwiększył odporność UE i strefy euro na zawirowania finansowe. Trudno jednak uznać, że jest to program kompletny 
i skończony, a w wielu dziedzinach widać wyraźne niedoskonałości powstającej nowej struktury instytucjonalnej. Lata odbudowy gospodarczej po kryzysie pandemicznym będą stanowić prawdziwy test pokazujący, w jakim stopniu udało się rozwiązać stojące przed UE problemy.

\section{Bibliografia}

Barcz J., Reforma strefy euro Unii Europejskiej. Na drodze do sanacji i konsolidacji, Elipsa, Warszawa 2013.

Bartsch E., Bénassy-Quéré A., Corsetti G., Debrun X., It's All in the Mix: How Monetary and Fiscal Policies Can Work or Fail Together, "Geneva Reports on the World Economy” 2020, nr 23.

Bénassy-Quéré A., Wolff G., How Has the Macro-Economic Imbalances Procedure Worked in Practice to Improve the Resilience of the Euro Area?, Brussels 2020, https://www.bruegel.org/wp-content/uploads/2020/03/ IPOL_STU2020645710_EN.pdf.

Calvo G., Servicing the Public Debt: The Role of Expectations, „American Economic Review” 1988, t. 78, nr 4.

Eckert S., Lindner V., Nölke A., EMU Reform Proposals and Their (non) Implementation: An Overview, „SAFE White Paper" 2021, nr 78, https://www.econstor.eu/bitstream/10419/228535/1/1743908407.pdf.

Eichengreen B.J., Frieden J., The Political Economy of European Monetary Unification: An Analytical Introduction, „Economics and Politics" 1993, t. 5, nr 2.

Grauwe P. de, The Economics of Monetary Integration, Oxford University Press, Oxford 1992.

Grauwe P. de, The Governance of a Fragile Eurozone , „CEPS Working Document” 2011, nr 346, https://papers.ssrn. com/sol3/papers.cfm?abstract_id=1898618.

Gros D., Thygesen N., European Monetary Integration, Longman, London 1998.

Juncker J.C., Tusk D., Dijsselbloem J., Draghi M., Schulz M., Completing Europe's Economic and Monetary Union, Brussels 2015.

Mody A., Eurotragedy: A Drama in Nine Acts, Oxford University Press, Oxford 2018.

Mundell R., The Euro and the Stability of the International Monetary System [w:] The Euro as a Stabilizer in the International Economic System, red. R. Mundell, A. Clesse, Springer, Boston 2000.

Mundell R., A Theory of Optimal Currency Areas, „American Economic Review” 1961, nr 51.

Orłowski W.M., Optymalna ścieżka do euro, Wydawnictwo Naukowe Scholar, Warszawa 2004.

Pisani-Ferry J., Euro Area Reform: An Anatomy of the Debate, "CEPR Policy Insight" 2018, nr 75, https://cepr.org/ sites/default/files/policy_insights/PolicyInsight95.pdf.

Schnabel I., The Shadow of Fiscal Dominance: Misconceptions, Perceptions and Perspectives, wystąpienia na Eurofi Financial Forum, Berlin 2020, https://www.ecb.europa.eu/press/key/date/2020/html/ecb. sp200911 ea32bd8bb3.en.html.

Strauch R., Lessons from the Euro Crisis, BBVA Seminar, Valencia, 23 January 2017, https://www.esm.europa.eu/ speeches-and-presentations/lessons-euro-crisis.

Thiemeyer G., Economic Models in France and Germany and the Debates on the Maastricht Treaty, "Journal of European Integration History" 2013, t. 19, nr 1.

Vandenbroucke F., Why we Need a European Social Union, „Reflets et Perspectives de la Vie Economique” 2013, t. 52 , nr 2/3.

Zsolt D. et al., European Union Countries'Recovery and Resilience Plans, Bruegel Datasets, 9 June 2021, https://www. bruegel.org/publications/datasets/european-union-countries-recovery-and-resilience-plans/. 


\section{Raporty, dokumenty}

Bank for International Settlements, About Credit Statistics, https://www.bis.org/statistics/about_credit_stats. htm?m=6\%7C380.

Bank for International Settlements, Residential Property Prices: Detailed Series (Nominal), 2021, https://www.bis. org/statistics/pp_detailed.htm?m=6\%7C288\%7C593.

Commission of the European Communities, Report of the Study Group on the Role of Public Finance in European Integration, Brussels 1977, http://aei.pitt.edu/36433/1/Report.study.group.A13.pdf.

Commission of the European Communities, Report to the Council and the Commission on the Realization by Stages of Economic and Monetary Union in the Community, Luxembourg 1970, https://ec.europa.eu/archives/ emu_history/documentation/chapter5/19701008en72realisationbystage.pdf.

Committee of European Banking Supervisors, Aggregate Outcome of the 2010 EU wide Stress Test Exercise Coordinated by CEBS in Cooperation with the ECB, 2010, https://www.eba.europa.eu/sites/default/documents/files/ documents/10180/15938/95030af2-7b52-4530-afe1-f067a895d163/Summaryreport.pdf?retry=1.

European Banking Authority, 2018 EU-wide Stress Test: Result, London 2018, https://www.eba.europa.eu/sites/ default/documents/files/documents/10180/2419200/126521e6-613f-45e4-af84-cbd3b854afc5/2018-EU-wide-stress-test-Results.pdf?retry=1.

European Commission, Next Generation EU: Commission Presents Next Steps for €672.5 Billion Recovery and Resilience Facility in 2021 Annual Sustainable Growth Strategy, Brussels 2020, https://ec.europa.eu/commission/ presscorner/detail/en/IP_20_1658.

European Commission, White Paper on the Future of Europe: Reflections and Scenarios for the EU27 by 2025, Brussels 2017, https://ec.europa.eu/commission/sites/beta-political/files/white_paper_on_the_future_of_europe_en.pdf.

European Parliament, The ESM and the IMF: Comparison of the Main Features, Brussels 2018, https://www.europarl. europa.eu/RegData/etudes/IDAN/2017/614485/IPOL_IDA(2017)614485_EN.pdf.

European Stability Mechanism, Safeguarding the Euro in Times of Crisis: The Inside Story of the ESM, Publications Office of the European Union, Luxembourg 2019.

Eurostat, https://ec.europa.eu/eurostat/web/main/data/database.

International Monetary Fund, World Economic Outlook Database, https://www.imf.org/en/Publications/WEO/ weo-database/2021/April.

McKinsey Global Institute, Debt and (Not Much) Deleveraging, London-San Francisco-Shanghai 2015, https:// www.mckinsey.com/ /media/mckinsey/featured\%20insights/employment\%20and\%20growth/debt\%20 and\%20not\%20much\%20deleveraging/mgi\%20debt\%20and\%20not\%20much\%20deleveragingfullreportfebruary2015.pdf.

McKinsey Global Institute, Visualizing Global Debt, https://www.mckinsey.com/business-functions/strategy-and-corporate-finance/our-insights/visualizing-global-debt.

OECD, Role of Banks, Equity Markets and Institutional Investors in Long-Term Financing for Growth and Development, Report for G20 Leaders, Paris 2013, https://www.oecd.org/finance/private-pensions/G20reportLTFinancingForGrowthRussianPresidency2013.pdf. 